\title{
Review
}

\section{The need for prognosticators in rheumatoid arthritis. Biological and clinical markers: where are we now?}

\author{
Josef S Smolen ${ }^{1,2}$, Daniel Aletaha ${ }^{1}$, Johannes Grisar ${ }^{1}$, Kurt Redlich ${ }^{1}$, Günter Steiner ${ }^{1}$ \\ and Oswald Wagner ${ }^{3}$
}

\begin{abstract}
1Division of Rheumatology, Department of Internal Medicine III, Medical University of Vienna, Waehringer Guertel 18-20, A-1090 Vienna, Austria $2^{\text {nd }}$ Department of Medicine, Hietzing Hospital, Wolkersbergenstrasse 1, A-1130 Vienna, Austria

${ }^{3}$ Department of Laboratory Medicine, Medical University of Vienna, Waehringer Guertel 18-20, A-1090 Vienna, Austria
\end{abstract}

Corresponding author: Josef S Smolen, josef.smolen@meduniwien.ac.at

Published: 29 May 2008

This article is online at http://arthritis-research.com/content/10/3/208

(c) 2008 BioMed Central Ltd

\begin{abstract}
Rheumatoid arthritis is a heterogeneous disease with respect to clinical manifestations, serologic abnormalities, joint damage and functional impairment. Predicting outcome in a reliable way to allow for strategic therapeutic decision-making as well as for prediction of the response to the various therapeutic modalities available today, especially biological agents, would provide means for optimization of care. In the present article, the current information on biological and clinical markers related to disease activity and joint damage as well as for predictive purposes is reviewed. It will be shown that the relationship of many biomarkers with disease characteristics is confounded by factors unrelated to the disease, and that only few biomarkers exist with some predictive value. Moreover, clinical markers appear of equal value as biomarkers for this purpose, although they likewise have limited capacity in these regards. The analysis suggests the search for better markers to predict outcomes and therapeutic responsiveness in rheumatoid arthritis needs to be intensified.
\end{abstract}

\section{Introduction: setting the stage}

Rheumatoid arthritis (RA) is characterized by many different phenotypes. Joint involvement, although characteristically symmetrical, can range from a monoarticular pattern to a highly polyarticular pattern, and joint damage can span from mild cartilage degradation to progressive erosive disease of juxtarticular bone [1,2]. The course of RA may be cyclic or relentlessly active [3], and extraarticular manifestations such as rheumatoid nodules or vasculitis may be present. Patients may be seronegative or may have many different autoantibodies [4]. Variable combinations of all these characteristics create a broad heterogeneity that is partly manifested by differences in disease outcomes spanning from remission to severe disability and premature mortality $[5,6]$. When therapeutic targets are tested in clinical trials and are prescribed in clinical practice, however, RA is still regarded as a single disorder.

\section{Biomarkers and clinical markers}

Disease activity, joint damage and functional impairment form the anchor points of the natural history of RA, and are characterized by a triangular interrelationship (Figure 1). It is well established that continued disease activity leads to joint damage, resulting in reduction of physical functioning - and if damage is progressive, to irreversible disability [7]. For any clinical and biological marker to be useful, therefore, it should reflect one or more of the components of the RA triad.

Traditionally, a marker in the present sense should constitute an indicator or a surrogate with diagnostic or prognostic utility [8] (Figure 1). A biological marker, then, would be involved in or would be a consequence of a pathological (or normal) biological process, a product of the organism that is measurable and thus bears the attribute of objectivity.

In the context of rheumatic diseases, a typical biomarker could be a gene or some product of gene expression, an autoantibody, a cytokine, an acute phase reactant, a tissue abnormality possibly visualized immunhistochemically in a synovial biopsy, or a tissue degradation product. The sources of these biomarkers could be the serum, urine, synovial fluid, tissue, cells, and so forth.

In contrast, a clinical marker would constitute a physical variable (sign or symptom), or a clinical judgment or outcome measurement, that emerges as a sequel of the underlying disease process. In rheumatology, this variable may be joint

$\mathrm{COL2}=$ type II collagen; CRP = C-reactive protein; CTX = collagen C-terminal telopeptide; DMARD = disease-modifying antirheumatic drug; IL = interleukin; NTX = collagen N-terminal telopeptide; RA = rheumatoid arthritis; RANKL = receptor activator of NFKB ligand; TNF $=$ tumor necrosis factor. 


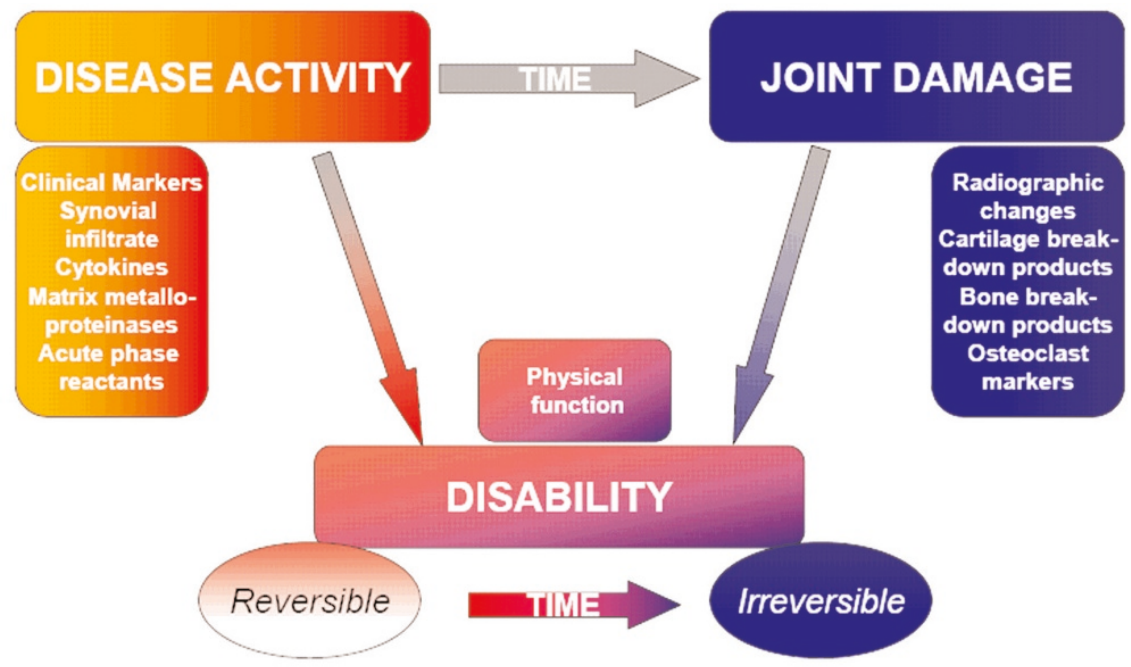

Triad of rheumatoid arthritis and a selection of markers reflecting its respective elements. The triad of rheumatoid arthritis comprises disease activity-joint damage-disability; a selection of markers that mainly reflect the respective elements of the triad are shown. Over time, the component of disability related to joint destruction will increase and thus disability becomes progressively less reversible; in contrast, with adequate therapy, the component of disability related to disease activity will always be reversible $[6,7,98]$.

counts, global or pain assessments and similar clinical variables, but also composite indices or functional or radiographic scores (reviewed in [9]). The sources of these clinical markers are the patients' manifestations as judged by an assessor or by the patients themselves, and they consequently carry a certain degree of subjectivity - which is less easy to standardize than many laboratory measures.

Any biological marker will therefore have to prove its value in relation to clinical markers, and not necessarily vice versa. Nevertheless, to be useful as true surrogate markers of disease, both types of markers have to reflect disease outcome in a broad sense; namely, a 'meaningful endpoint of how a patient feels, functions and survives' [10]. At present, therefore, none of the available biological markers or clinical markers can be employed as surrogate markers, since as such they would have to be useful as substitutes for a clinical outcome. Also, a measure that is useful as a biomarker needs to be validated objectively by demonstration that the laboratory test is accurate, reproducible and measures what it is supposed to. This is not clear for all molecules measured in body fluids that will be mentioned. With these caveats in mind, we will nevertheless use the term biomarker or biological marker in the course of the present review for the biological measurements discussed here, for the sake of simplicity and since this term has been frequently used for these measurements by many experts in the field [11,12].

The present review will address several questions. Can biologic or clinical markers eventually help to subset patients into those who may or may not respond therapeutically to a given medication? Is there evidence that biomarkers as presumed reflections of pathogenesis are more helpful for subsetting disease and therapeutic prognostication than clinical markers? Are biomarkers more sensitive to change than clinical markers? Do targeted therapies elicit characteristic biomarker signatures in the sense of a proof of concept?

\section{Biological markers of joint damage}

Joint damage in RA is due to changes of cartilage and bone. Radiologically, cartilage changes are reflected by joint space narrowing, while erosions signify bone destruction [13]. Different biomarkers will consequently be representative of these two components of RA joint destruction.

\section{Cartilage and bone markers}

Cartilage damage - regardless of its cause - will lead to changes in matrix composition. Cartilage matrix is composed of a mesh of type II collagen (COL2), the most abundant cartilage protein. Collagen consists of three chains that form a triple helix, with the exception of the nonhelical $\mathrm{N}$-terminal and C-terminal ends, the telopeptides. In the extracellular matrix, the collagen molecules are linked to one another by cross-linking molecules such as pyridinoline; this crosslinking involves the telopeptides. While the nonhelical parts are degradable by many enzymes, the helical portion can only be degraded by mammalian collagenase at a specific site that yields fragments of one-quarter and three-quarter lengths, respectively. During cartilage degradation, therefore, different collagen fragments - such as crosslinked C-terminal and $\mathrm{N}$ terminal telopeptides - are released (Table 1). Likewise, alpha chain fragments of collagenase degradation are set 
Table 1

\begin{tabular}{|c|c|c|c|}
\hline Tissue & Molecule & Marker of degradation & Designation \\
\hline \multirow[t]{6}{*}{ Cartilage } & Type II collagen & Pyridinoline & PYD \\
\hline & & Type II collagen C-terminal and $\mathrm{N}$-terminal telopeptides & CTX-II, NTX-II \\
\hline & & Type II collagen alpha chain fragments & Col2-3/4 long, Col2-3/4C short \\
\hline & Aggrecan & Core protein fragments & \\
\hline & & Keratan sulfate fragments & \\
\hline & $\begin{array}{l}\text { Noncollagen and } \\
\text { nonaggrecan proteins }\end{array}$ & Cartilage oligomeric matrix protein & COMP \\
\hline \multirow[t]{4}{*}{ Bone } & Type I collagen & Pyridinoline, deoxypyridinolin & PYD, DPD \\
\hline & & Type I collagen C-terminal and N-terminal telopeptides & CTX-I, NTX-I \\
\hline & $\begin{array}{l}\text { Noncollagenous } \\
\text { proteins }\end{array}$ & Bone sialoprotein & BSP \\
\hline & & Tartrate-resistant acid phosphatase & TRAP \\
\hline
\end{tabular}

free and can be measured, such as COL2 three-quarter-long collagen via the generated carboxyterminal neoepitope.

Within the COL2 network, other components of the cartilage matrix are interspersed. These components are degraded in the course of cartilage damage. Among these are aggrecan, the breakdown products of which can be detected via core protein, keratan sulfate or chondroitin sulfate epitopes, and cartilage oligomeric matrix protein.

Bone destruction is an important hallmark of RA, and therefore the ability to measure its surrogates is important. The major structural protein of bone is type I collagen, which like COL2 forms triple helical, cross-linked structures and is degraded in a similar manner as COL2. Type I collagen Cterminal telopeptide (CTX-I) and type I collagen N-terminal telopeptide (NTX-I), but also free pyridinoline crosslinks, therefore reflect type I collagen degradation. Just like cartilage, bone contains noncollagenous proteins, such as bone sialoprotein, which are released during bone damage (Table 1).

\section{Association with joint damage}

Landewe and colleagues have shown a significant correlation between early changes in type II collagen C-terminal telopeptide (CTX-II) and prediction of long-term radiographic progression as a result of therapy; in contrast, changes of CTX-I were not related to joint damage $[14,15]$. The changes in CTX-II levels, however, were broadly overlapping with baseline values, and were therefore predictive primarily on a group level. Subanalysis of radiographic changes by joint space narrowing and erosion scores did not reveal major differences between these two components of the radiographic score in relation to these biomarkers [14]. This analysis indicates that CTX-II levels may at least partly reflect the inflammatory response (which leads to collagen degradation via activation of matrix metalloproteinases), although there was no statistical evidence for such relationship. In contrast, MMP3 levels appear significantly associated with progression of joint damage $[16,17]$.

Assessment of COL2 three-quarter-long collagen showed decreasing levels during treatment with methotrexate, and particularly with anti-TNF + methotrexate [16]. Moreover, baseline COL2 three-quarter-long collagen concentrations were significantly associated with cytokine levels [16].

Evaluation of cartilage oligomeric matrix protein levels revealed that these are much higher in patients whose joint damage progresses when compared with those whose radiographic changes do not progress [18]. These observations as well as the CTX-II data were recently confirmed [17], although there was again broad overlap in biomarker levels of patients with and without progression of joint damage. Yet none of these markers performed better than C-reactive protein (CRP), swollen joint counts or composite disease activity indices [17].

Another set of markers potentially useful to assess bone damage relates to osteoclast differentiation and function. Osteoclasts that derive from bone marrow progenitor cells via the monocyte lineage are the cell population responsible for erosive changes $[19,20]$ and are pivotally dependent on the triggering of receptor activator of $\mathrm{NF} K \mathrm{~B}$. The receptor activator of NFKB ligand (RANKL), a member of the TNF family, is expressed on various cell populations and also exists as a soluble molecule [21]. The ligand's action can be inhibited by osteoprotegerin, a decoy receptor. Both osteoprotegerin and RANKL can be measured in serum, and the 
osteoprotegerin/RANKL ratio may be an indicator of osteoclast differentiation and activation. In fact, a low osteoprotegerin/RANKL ratio, reflecting high RANKL activity, appears to be associated with increased progression of radiographic joint damage [22]. Osteoclasts mediate their special function in degrading calcified bone by several mechanisms, including secretion of cathepsin K. Consequently, cathepsin K levels correlate with joint destruction [23] and may be reflective of effective therapy [24].

Despite some interesting, although mostly inconclusive, data in the literature, there are a number of confounding factors related to the usefulness of many of these bone and cartilage breakdown products in helping to subgroup and treat RA. First, comorbidity, such as osteoarthritis and especially generalized osteoporosis [25], may lead to collagen degradation and thus obscure the subtle changes observed. Another factor is that circadian variations in bone and cartilage marker levels have been described (that is, the timing of the measurement is critical) $[26,27]$. Third, physical activity may change biomarker concentrations significantly [28]. A fourth factor is that renal or hepatic disease may influence circulating and/or urine levels of biomarkers [29]; especially, urine biomarkers should always be related to creatinine levels [11]. Finally, the tissue content and/or levels of certain proteins that constitute useful biomarkers may be genetically determined, and this heritability may have to be accounted for [30]. These factors contribute to the complexity of monitoring cartilage and bone turnover in RA as they relate to predicting joint damage [31]. In an individual patient, however, short-term changes in the course of therapeutic interventions aimed at interfering with the RA process ought to reflect the modification of that process.

Another set of markers that is not derived from cartilage or bone may be predictive of joint damage: autoantibodies. It has long been recognized that radiographic progression of joint destruction is much higher in patients positive for rheumatoid factor when compared with seronegative patients [32-35]. This is particularly true in patients with high-titer rheumatoid factor; that is, rheumatoid factor $\geq 50 \mathrm{IU} / \mathrm{ml}$ [36]. Autoantibodies to citrullinated proteins have been shown more recently to be predictive for the occurrence of erosions [36,37]; the autoantibodies are broadly overlapping with high-titer rheumatoid factor, and the latter appears to change with effective therapy more than the autoantibodies to citrullinated proteins $[35,36,38,39]$. These markers of the autoimmune response characteristic of RA surpass the value of most cartilage and bone breakdown products in predicting joint damage. At present, the combination of autoantibody and acute phase protein assessment may constitute the most reliable way to predict severe erosive RA $[33,40]$.

\section{Biological markers of disease activity Cells and cytokines}

The clinical manifestations of RA are the consequences of synovial inflammation and the subsequent degradation and destruction of cartilage and bone. These pathways comprise various cell populations characteristically involved in RA synovitis as well as cytokines and the products of their action.

When looking at arthroscopic biopsies, the composition of the cellular infiltrate is heterogeneous $[41,42]$, and the most consistent reflection of active disease is the presence of high numbers of macrophages in the synovium $[43,44]$. Potent anti-inflammatory agents such as glucocorticoids lead to a reduction in synovial macrophage cellularity (but little other cellular changes) [45]. Interestingly, blocking other mediators such as the chemokine macrophage chemoattractant protein MCP-1 was not associated with changes of synovial tissue composition or with clinical benefit $[39,46]$. In addition, the degree of B-cell depletion in synovial tissue in the course of rituximab therapy was not significantly associated with the clinical response and $B$ cells may be present in the synovium even if depelted in peripheral blood $[39,47]$. This finding also indicates that the periphery often does not reflect the events occurring in the joint, but these by themselves are also not sufficiently predictive.

With the exception of macrophage infiltrates, therefore, the composition and extent of the cellular infiltrate may not be related to clinical manifestations, in line with observations of histologic synovitis in the absence of clinical joint involvement [48]. Likewise, the immunohistochemistry of cytokines may not sufficiently reflect the disease activity of RA. The use of gene expression profiling currently does not appear to provide much additional information in this respect $[49,50]$, although the technique may be useful to detect unforeseen changes. Serum levels of proinflammatory cytokines including the most abundant one, IL-6 - are not highly correlated with measures of disease activity and progression [51,52]; moreover, baseline IL-6 concentrations may vary almost 100-fold between different individuals, and can increase with exercise [53].

Qualitative and/or quantitative differences exist among individual patients both on the cellular level and the cytokine level [54,55], and pathohistologic analyses have failed to reveal changes that are pathognomonic for RA. Synovial cytokine expression in RA, even at a group level, does not significantly differ qualitatively from other arthritic disorders [56-58]. Nevertheless, there appear to be differences in the quantity of cytokine expression when looking at other inflammatory joint diseases, such as psoriatic arthritis, ankylosing spondylitis or inflammatory osteoarthritis. Patients with these conditions have lower synovial TNF and IL-6 levels than RA patients $[58,59]$. These differences may have some important bearing given that RA is a rapidly and highly destructive joint disease, while the other disorders are usually slowly or not as destructive.

All these facets reveal the complexity we face when trying to search for good biomarkers. The complexity is further 
illustrated by observations that changes found in these markers early in the course of RA may be quite different from those seen in late disease [60], regardless of the level of activity or inflammation in either early or late disease.

To better appreciate the complexity, we present four hypothetical patients in whom different cytokines or different cell populations may appear to predominate, even though in all patients many cells or soluble molecules are at least partly activated (Figure 2).

The resolution of this mosaic will be difficult: changes of biomarker levels in the course of therapy may give helpful insights, but this knowledge is insufficient to provide prediction rules for the employment of specific therapies.

\section{Acute phase reactants}

In contrast to the markers mentioned above, the serum levels of CRP, a molecule induced by proinflammatory cytokines, especially IL-6 [61], not only reflect the extent of disease activity $[62,63]$ but are also cumulatively associated with joint destruction [17,63,64]. Moreover, CRP levels before the start of disease-modifying therapy can predict the degree of subsequent radiographic joint damage, and greater reduction from baseline in CRP levels was associated with less progression of joint damage and higher trough serum concentrations of anti-TNF antibody $[65,66]$. While other acute phase reactants, such as serum amyloid A protein, also reflect disease activity, CRP determination is widely available and of low cost [67], making it the preferred biomarker of disease activity (and even joint destruction) not yet surpassed by other markers.

The erythrocyte sedimentation rate could be regarded as an alternative to measuring CRP. However, it may be influenced by various other factors not primarily related to inflammation [68]. Successful therapeutic interventions with glucocorticoids and disease-modifying antirheumatic drugs (DMARDs) including biological agents are usually associated with a fall in CRP levels, and are often also paralleled by reductions in IL-6 serum concentrations $[24,69,70]$.

It is somewhat disappointing that levels of other marker molecules, such as various cytokines, cytokine receptors or matrix metalloproteinases, have not been shown to exhibit better correlations with actual disease manifestations or outcomes of RA than acute phase reactants. No biological marker assessed hitherto has therefore been shown to be related better to disease activity and joint damage than CRP.

\section{Clinical markers}

Biological markers have to reflect diagnosis and/or prognosis; that is, clinical outcomes $[10,71]$. The extent of this association will determine the reliability and value of the marker. As revealed above, with the exception of the acute phase response and autoantibodies, no biological marker is currently sufficiently reliable to acknowledge its usefulness as a marker of disease activity or joint damage for use in clinical practice. Markers of disease activity, however - especially composite indices using some of the core set variables, such as the Disease Activity Score employing 28 joint counts, the Simplified Disease Activity Index and the Clinical Disease Activity Index (reviewed in [9]) - have been shown useful for following disease activity and for serving as endpoints in clinical trials and observational studies [72,73]. Moreover, disease activity over time as assessed using these indices correlates significantly with progression of joint damage [63].

These data suggest that clinical markers, even in the absence of any laboratory variable such as is the case with the Clinical Disease Activity Index [63], may serve the purpose of predicting joint damage at least as well as any biological marker. In fact, time-averaged disease activity using these composite indices correlated with radiographic progression better than time-averaged CRP [63].

\section{Prediction of clinical improvement and retardation of joint damage}

No biomarker currently allows one to predict the extent of clinical improvement in response to therapy, although the degree of radiographic progression on traditional diseasemodifying agents can be foretold by baseline and cumulative levels of CRP, swollen joint counts or overall disease activity using respective composite scores [65].

In this context it needs to be borne in mind that TNF and IL- 6 are cytokines that promote osteoclast differentiation and activation [20,21,74-77]. Importantly, under stable low concentrations of RANKL, increasing amounts of proinflammatory cytokines, such as TNF, will lead to increasing osteoclast differentiation [78]. It is therefore conceivable that this relation of TNF levels and osteoclast activation also exists in vivo. In support of this notion, treatment of RA patients with a TNF inhibitor plus methotrexate leads to a dissociation of the close relationship between joint damage and the inflammatory response (exemplified by disease activity measures) [79], and these data were meanwhile confirmed with another TNF-blocker [80]. These findings have led to the threshold hypothesis shown in Figure 3. According to this hypothesis, TNF will lead to joint damage especially once its levels exceed a particular threshold that lies above the threshold needed for the activation of the inflammatory response. Blocking of TNF may inhibit its bioactivity fully (Figure 3b), may reduce bioactivity to levels below the putative threshold of destruction with residual signs and symptoms but no destruction (Figure 3c), or may reduce bioactivity to levels above that threshold but still significantly retard joint damage compared with other treatment modalities, without preventing progression in full (Figure 3d). This hypothesis is in line with results from clinical trials where the use of TNF inhibitors significantly retarded or halted joint destruction despite residual active disease [81-83]. 


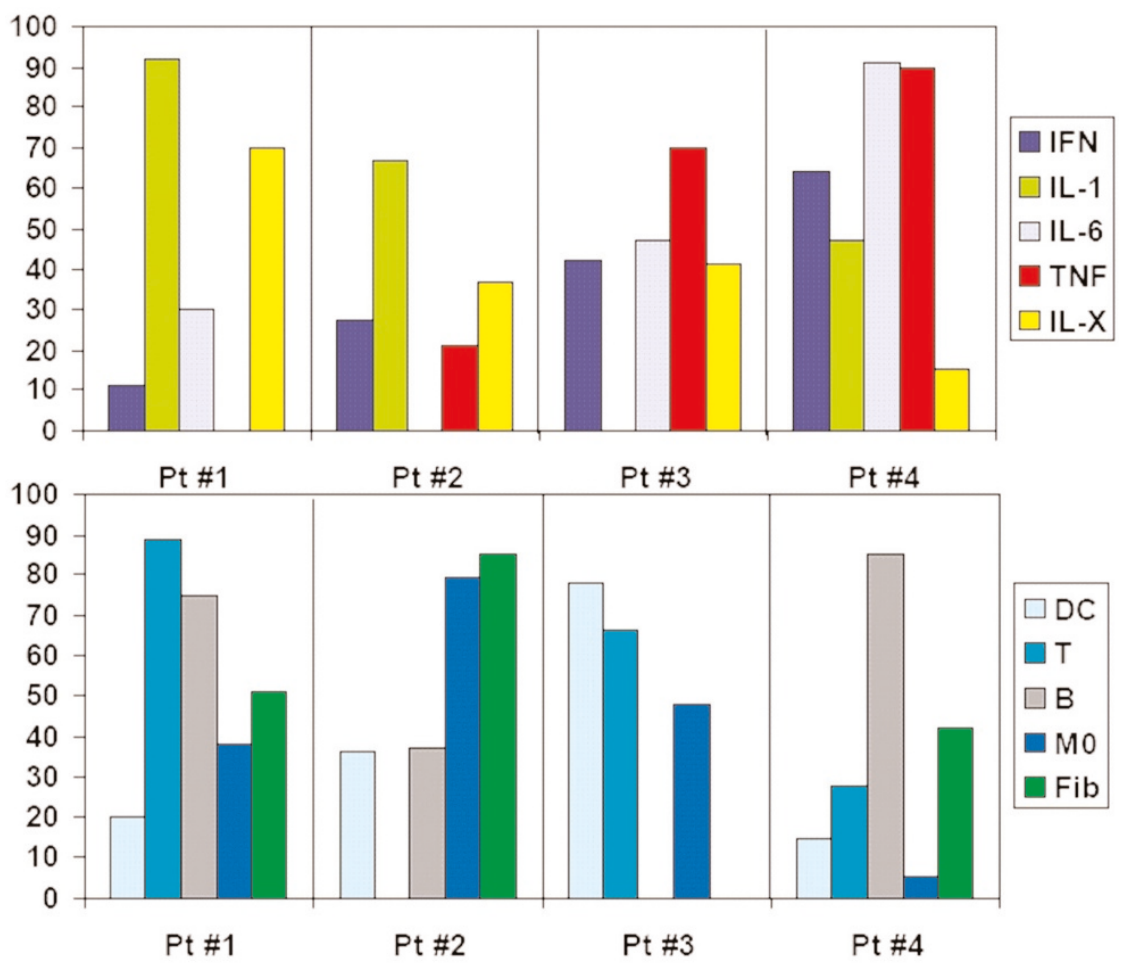

Depiction of potential cytokine and cellular patterns in four hypothetical patients with rheumatoid arthritis. Upper panel: hypothetical biological activities of various cytokines. Lower panel: hypothetical biological activities of various cell types. $y$ axis, arbitrary units of activity. For example, in patient \#1 TNF does not appear bioactive, while in patient \#3 B cells appear uninvolved. Especially in patient \#4, however, all cytokines - and in patient \#1 all cell types - appear actively engaged in the disease process. In patient \#2 IL-6 may not be detectable. It is unclear to what extent which of those cells and/or cytokines is contributing and if one or several targeted therapies would be efficacious. Although such relationships have not yet been elucidated, differences in synovial cellular compositions and cytokine contents have been noted in various studies [55,59,99]. DC, dendritic cells; Fib, fibroblasts.

Whilst the focus of attention with respect to joint damage has primarily been the osteoclast, it should be borne in mind that bone repair mechanisms may be deficient in TNF-mediated arthritis and can be induced by osteoblast activation [84]. Biomarkers of osteoblast function, including proteins involved in the Wnt signaling pathways [85], may therefore constitute further interesting markers for the future.

Importantly, however, achieving low disease activity or remission with traditional DMARDs will lead to highly effective reduction of progression of joint damage [86]. Another important aspect in our attempts to predict outcomes is therefore the estimation of the clinical response to treatment.

Recent analyses in a large cohort of clinical trial patients have revealed that baseline disease activity is already somewhat related to disease activity at 1 year of therapy, especially with methotrexate treatment [87]. Irrespective of the type of therapy or disease duration, however, 3 months after initiation of treatment the disease activity - as assessed by the Simplified Disease Activity Index, the Clinical Disease Activity Index or the Disease Activity Score employing 28 joint counts - was highly correlated with disease activity at the end of the observation period [87] (Figure 4). These data were further validated by studying an observational cohort of RA patients [88]. The probability to attain remission or low disease activity was more than $75 \%$ for patients achieving low disease activity by the Simplified Disease Activity Index already after 3 months of treatment, while it amounted to only $25 \%$ for patients having high disease activity at that point in time [87].

Needless to say, achieving lower disease activity after 3 months of therapy will also result in better outcomes in the other components of the triad - physical function and joint damage. Moreover, starting effective treatment early, and especially before initial damage has occurred, constitutes the optimal strategy (Figure 5). This optimization, however, requires early referral and early diagnosis [89,90]. Moreover, there is sufficient evidence to allow stating that DMARDs will interfere with the disease process at any point in time and will prevent progression of disease regardless of patient age or disease duration - it is the past damage that has to be carried on. 
(a)

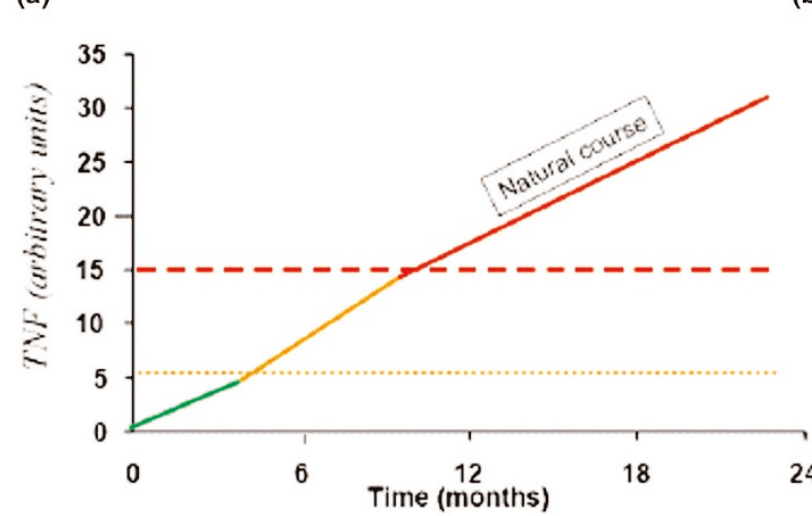

(c)

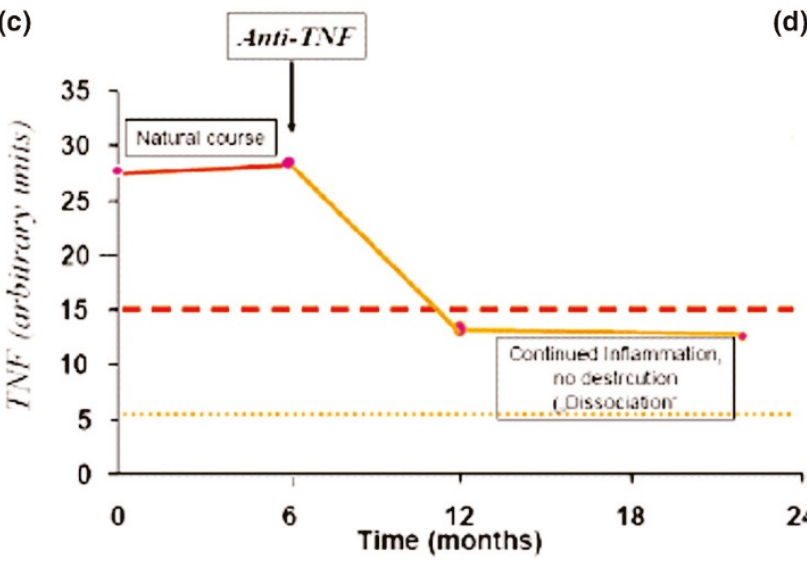

(b)

(d)
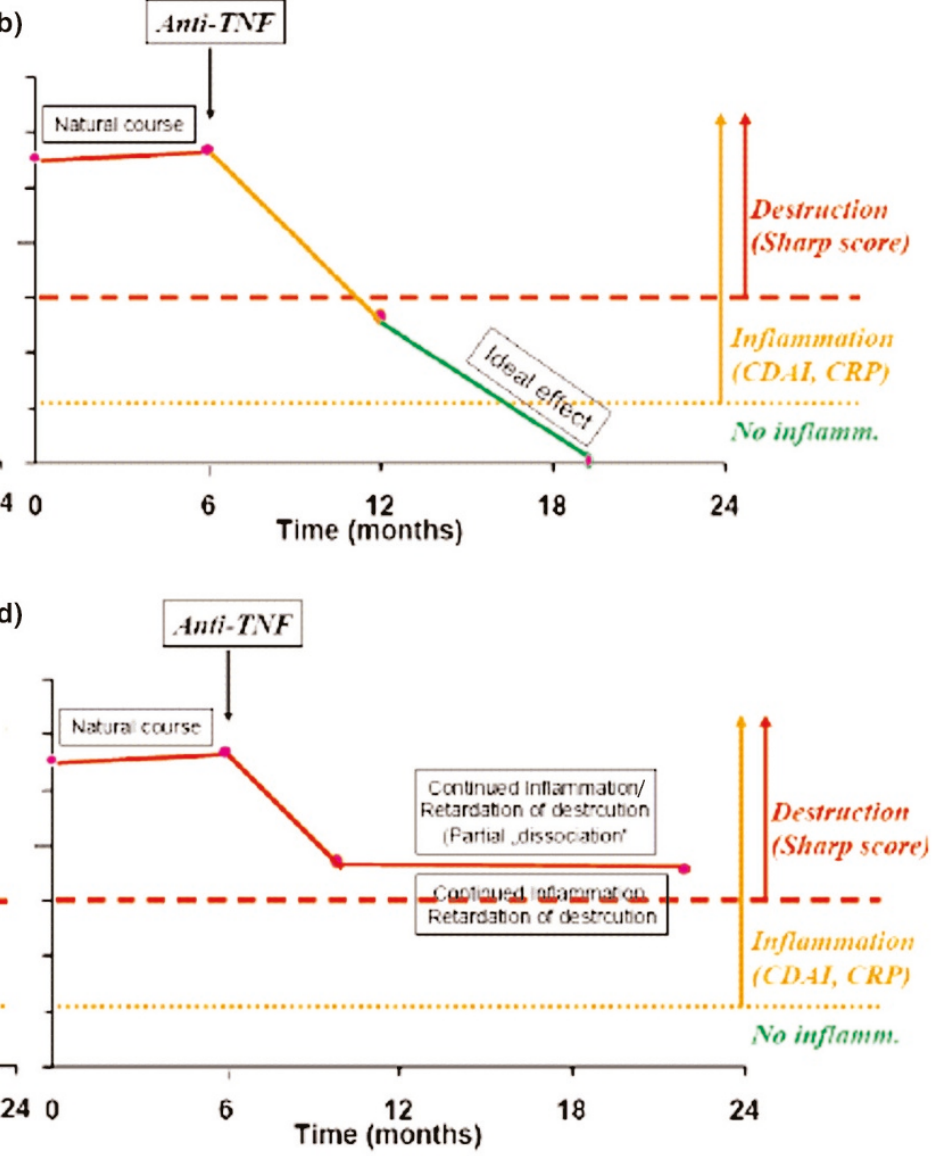

Threshold hypothesis of osteoclast activation. (a) Osteoclast activation is assumed to occur only after passing a putative threshold. (b) Anti-TNF therapy may ideally lead to total inhibition of bioactive TNF. (c) In other patients, anti-TNF therapy may reduce TNF activity below the threshold of osteoclast activation; these patients may continue having signs and symptoms of rheumatoid arthritis. (d) In yet another group of patients, the TNF activity may be reduced, but not to a level that goes below the threshold of osteoclast activation; in these patients, there will be more inflammation than in (c) and some residual destruction - in relation to other therapies, such as methotrexate, the destruction will be significantly less at a similar level of inflammatory signs and symptoms of rheumatoid arthritis [79]. CDAl, Clinical Disease Activity Index; CRP, C-reactive protein.

\section{Complexity of rheumatoid arthritis}

The ability to ulitilize biologic markers and or clinical markers to predict disease outcomes as well as therapeutic response early in the course of the disease, so as to achieve remission, is our ultimate goal in RA. We have indicated that predicting disease outcome and therapeutic response may be difficult due to the heterogeneity of the disease regarding both its clinical manifestations as well as putative pathogenic characteristics. Contributing to this has been the observed variability of biomarker levels. Data presently reveal that different therapeutic agents, including targeted therapies directed against different molecules, lead to similar therapeutic responses. To which degrees these responsive populations overlap, however, is currently unclear: do most of the patients achieving an American College of Rheumatology 70\% response (or remission) to one drug have different characteristics than patients responding to a similar extent to another agent, or are they overlapping? Answers to these questions are mandatory for institution of proper treatment to gain control of disease and to induce remission.

\section{Conclusion}

Many biological markers reflect the ongoing disease process of RA. The markers' correlation to the typical manifestations of RA, the signs and symptoms of active disease, the destruction of joints or the impairment of physical function, however, has been poor for most of them. This may be due to a variety of reasons. First, what we measure in various body fluids may not reflect sufficiently well what is ongoing in the microenvironment of the joint, and the leakage of various molecules into the body fluids may differ among, and within, patients. Second, where biomarkers have important pathophysiological functions, the concentrations measured may not reflect their functional fraction. Third, the pathogenesis of RA 


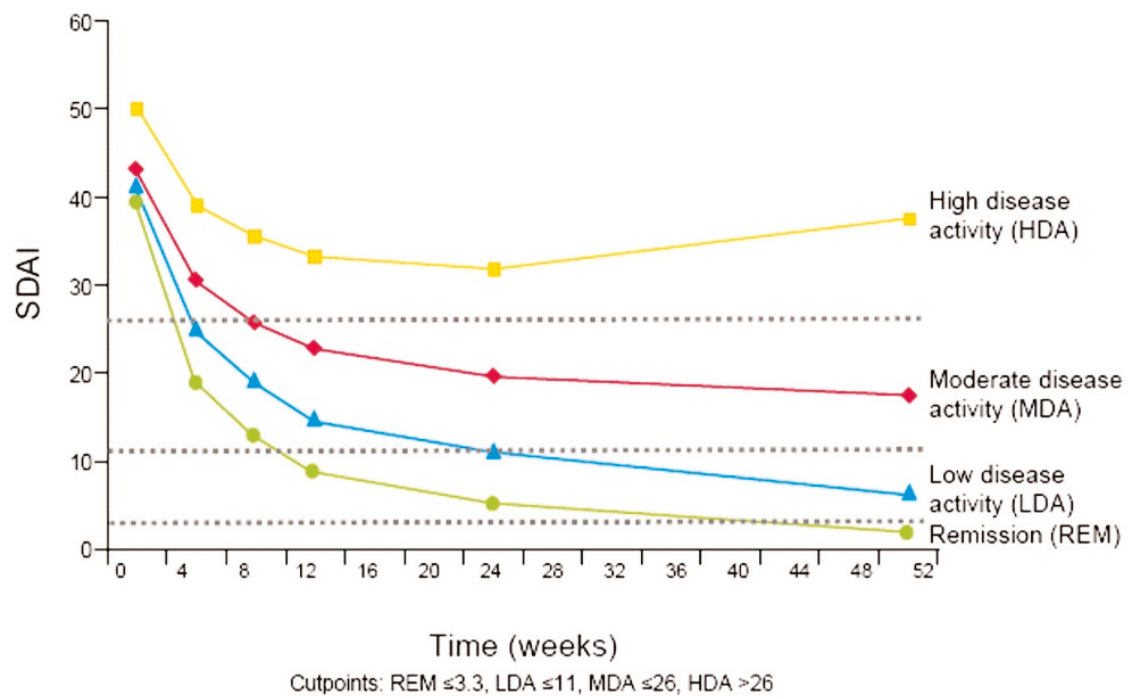

Time course of disease activity in patients attaining particular disease activity states after 1 year of therapy. Patients who achieved low disease activity or remission at 1 year attained a low disease activity state within 3 to 6 months from the onset of treatment. SDAl, Simplified Disease Activity Index. Reproduced with permission from [87].

\section{Figure 5}

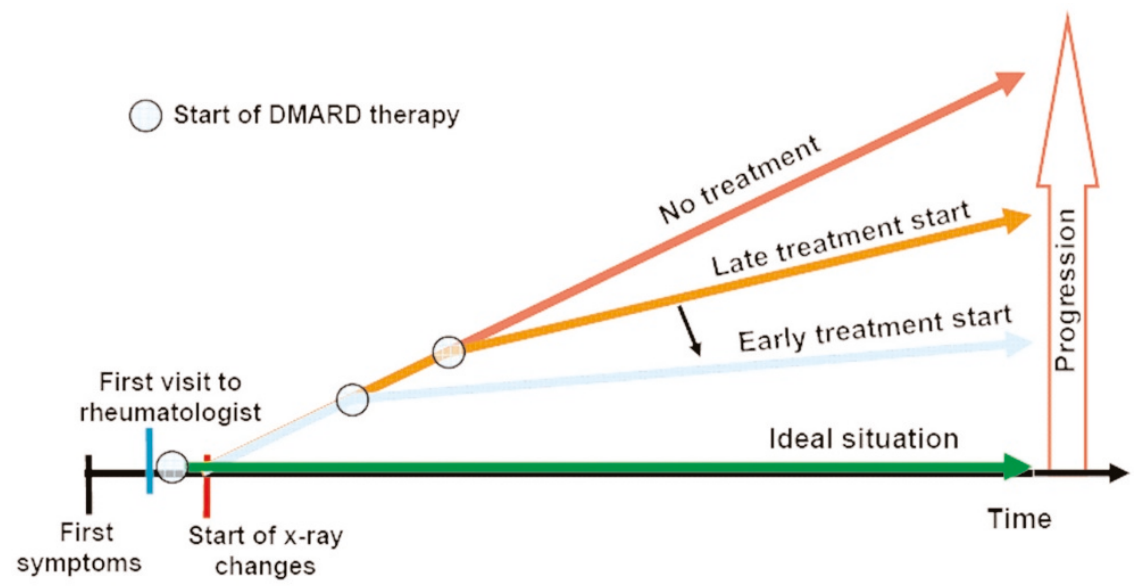

Effect of disease-modifying antirheumatic drug therapy. Disease-modifying antirheumatic drugs (DMARDs) will interfere with the disease process at any time point, and will lead to a deflection of the slope of progression from its natural course. The ideal situation would be to diagnose and treat rheumatoid arthritis early; at best, before damage has occurred.

may be highly heterogeneous, with different markers being preponderate in different patients. Fourth, pathogenetic mechanisms may even vary within a patient in the course of the disease. Finally, diurnal and genetic variations may change biomarker levels and confound our ability to interpret them - with relatively low levels in one patient being highly pathogenic, while a high level in another patient may mean little for that particular patient's disease.
Importantly, we have focused here on markers that are frequently used to evaluate disease activity, cartilage and bone damage. There is more going on in relation to the immunopathogenic events, however, than mere production of cytokines and the consequences of their activity. For example, certain T-cell subpopulations have shown changes in active RA [91,92]. The application of such markers in practice, however, is limited by the lack of widespread availability of the 
respective detection techniques. Also, some imaging techniques, such as magnetic resonance imaging and ultrasound, may allow new insights and may contribute interesting information on disease activity or even outcome [93-95].

More information is presently needed, and the search for the best set of biomarkers for assessment and prediction of disease activity, damage and response to therapy as well as efforts to better standardize biomarker assessment must, and will, go on. Appropriate cohorts of patients and appropriate validation procedures will be needed to this end. For the time being it appears too early to recommend the use of these markers in routine practice or as major outcomes in clinical trials. System biologic approaches may provide better insights in the not too distant future [96], but their applicability in routine settings will constitute yet another challenge. Likewise, proteomic approaches employing various methodological means may prove helpful, but at present merely confirm the complexity of the biological interplay we are dealing with in RA [97].

There are two exceptions, however, which make the above summary much less disappointing: acute phase reactants, especially CRP, are highly reliable markers of disease activity and, in the long term, radiographic outcomes; and autoantibodies, especially rheumatoid factor and autoantibodies to citrullinated proteins, have diagnostic and prognostic value. That these old markers surpass the value of new ones and that some of the old techniques employed for marker determination may be more reliable than new ones sounds inadequate, but nevertheless it is satisfying that such usefulness and validity does exist for at least few molecules.

Equally important, research activities of the past decade have allowed one to obtain clinical assessment tools - the composite disease activity indices, which are not only reliable for assessing the wellbeing of patients with RA during follow up, but are also highly associated with functional and radiological disease outcome. A combination of such tools with a novel approach to biomarker evaluation may therefore allow for optimized understanding and prediction of the fate of the individual RA patient. There is recognition that clinical assessment (measuring and noting the change in index and the disease activity state attained) early in the course of therapy ( 3 to 6 months after initiation of therapy) allows one to judge longer-term treatment effects and to make rapid changes of therapeutic modalities in the individual patients in whom low disease activity is not achieved. Such a strategy will consequently be associated with lesser costs by avoiding prolonged use of ineffective therapies and will also lead to a better outcome of RA.

\section{Competing interests}

The authors have received honararia and/or grant support from Abbott, Amgen, BMS, Centocor, Roche, Sanofi-Aventis, Schering-Plough, UCB and Wyeth. There has been no financing of the current manuscript by any of the above.

\section{Acknowledgements}

The authors would like to acknowledge the critical reading and suggestions by Dr Joseph Markenson. This paper was supported by the Center of Musculoskeletal Disorders, Medical University of Vienna.

\section{References}

1. van der Heijde DM, van Leeuwen MA, van Riel PL, Koster AM, van't Hof MA, van Rijswijk MH, van de Putte LB: Biannual radiographic assessments of hands and feet in a three-year prospective followup of patients with early rheumatoid arthritis. Arthritis Rheum 1992, 35:26-34.

2. Plant MJ, Jones PW, Saklatvala J, Ollier WE, Dawes PT: Patterns of radiological progression in early rheumatoid arthritis: results of an 8 year prospective study. J Rheumatol 1998, 25:417-426.

3. Masi AT: Articular patterns in the early course of rheumatoid arthritis. Am J Med 1983, 75(6A):16-26.

4. Steiner G, Smolen JS: Autoantibodies in rheumatoid arthritis. In Rheumatoid Arthritis. Edited by Firestein GS, Panayi GS, Wollheim FA. 2nd edition. Oxford: Oxford University Press; 2006:193-198.

5. Pincus T, Brooks RH, Callahan LF: Prediction of long-term mortality in patients with rheumatoid arthritis according to simple questionnaire and joint count measures. Ann Intern Med 1994 120:26-34

6. Drossaers-Bakker KW, de Buck M, van Zeben D, Zwinderman $\mathrm{AH}$, Breedveld FC, Hazes JM: Long-term course and outcome of functional capacity in rheumatoid arthritis: the effect of disease activity and radiologic damage over time. Arthritis Rheum 1999, 42:1854-1860.

7. Aletaha D, Smolen J, Ward MM: Measuring function in rheumatoid arthritis: identifying reversible and irreversible components. Arthritis Rheum 2006, 54:2784-2792.

8. Lassere MN, Johnson KR, Boers M, Tugwell P, Brooks P, Simon L, Strand V, Conaghan PG, Ostergaard M, Maksymowych WP, Landewe R, Bresnihan B, Tak PP, Wakefield R, Mease P, Bingham CO 3rd, Hughes M, Altman D, Buyse M, Galbraith S, Wells $G$ : Definitions and validation criteria for biomarkers and surrogate endpoints: development and testing of a quantitative hierarchical levels of evidence schema. J Rheumatol 2007, 34:607-615.

9. Aletaha D, Smolen JS: The definition and measurement of disease modification in inflammatory rheumatic diseases. Rheum Dis Clin North Am 2006, 32:9-44.

10. Temple RJ: A regulatory authority's opinion about surrogate endpoints. In Clinical Measurement in Drug Evaluation. Edited by Nimmo WS, Tucker GT. New York: John Wiley and Sons Inc.; 1995:5-23.

11. NIH White Paper: Biomarkers, the Osteoarthritis Initiative. Bethesda: National Institutes of Health; 2000.

12. Lassere MN, Johnson KR, Boers M, Tugwell $P$, Brooks $P$, Simon L, Strand V, Conaghan PG, Ostergaard M, Maksymowych WP Landewe R, Bresnihan B, Tak PP, Wakefield R, Mease P, Bingham CO 3rd, Hughes M, Altman D, Buyse M, Galbraith S, Wells G: Definitions and validation criteria for biomarkers and surrogate endpoints: development and testing of a quantitative hierarchical levels of evidence schema. J Rheumato/ 2007, 34:607-615.

13. van der Heijde D, Simon L, Smolen J, Strand V, Sharp J, Boers M, Breedveld F, Weisman M, Weinblatt M, Rau R, Lipsky P: How to report radiographic data in randomized clinical trials in rheumatoid arthritis: guidelines from a roundtable discussion. Arthritis Rheum 2002, 47:215-218.

14. Landewe R, Geusens $P$, Boers $M$, van der HD, Lems W, te KJ, Koppele J, van der Linden S, Garnero P: Markers for type II collagen breakdown predict the effect of disease-modifying treatment on long-term radiographic progression in patients with rheumatoid arthritis. Arthritis Rheum 2004, 50:1390-1399.

15. Landewe RB, Geusens P, Van der Heijde DM, Boers M, van der Linden SJ, Garnero P: Arthritis instantaneously causes collagen type I and type II degradation in patients with early rheumatoid arthritis: a longitudinal analysis. Ann Rheum Dis 2006, 65:40-44.

16. Visvanathan S, Marini JC, Smolen JS, Clair EW, Pritchard C, Shergy W, Pendley C, Baker D, Bala M, Gathany T, Han J, Wagner C: Changes in biomarkers of inflammation and bone turnover and associations with clinical efficacy following infliximab plus methotrexate therapy in patients with early 
rheumatoid arthritis. J Rheumato/ 2007, 34:1465-1474.

17. Young-Min S, Cawston T, Marshall N, Coady D, Christgau S, Saxne T, Robins S, Griffiths I: Biomarkers predict radiographic progression in early rheumatoid arthritis and perform well compared with traditional markers. Arthritis Rheum 2007, 56:3236-3247.

18. den Broeder AA, Joosten LA, Saxne T, Heinegård D, Fenner $H$, Miltenburg AM, Frasa WL, van Tits LJ, Buurman WA, van Riel PL, van de Putte LB, Barrera P: Long term anti-tumour necrosis factor alpha monotherapy in rheumatoid arthritis: effect on radiological course and prognostic value of markers of cartilage turnover and endothelial activation. Ann Rheum Dis 2002, 61:311-318.

19. Pettit $A R$, Ji $H$, von Stechow $D$, Muller $R$, Goldring $S R$, Choi $Y$, Benoist C, Gravallese EM: TRANCE/RANKL knockout mice are protected from bone erosion in a serum transfer model of arthritis. Am J Pathol 2001, 159:1689-1699.

20. Redlich K, Hayer S, Ricci R, David JP, Tohidast-Akrad M, Kollias G, Steiner G, Smolen JS, Wagner EF, Schett G: Osteoclasts are essential for TNF-alpha-mediated joint destruction. J Clin Invest 2002, 110:1419-1427.

21. Teitelbaum SL: Bone resorption by osteoclasts. Science 2000, 289:1504-1508

22. Geusens PP, Landewé RB, Garnero P, Chen D, Dunstan CR, Lems WF, Stinissen $P$, van der Heijde DM, van der Linden $S$, Boers M: The ratio of circulating osteoprotegerin to RANKL in early rheumatoid arthritis predicts later joint destruction. Arthritis Rheum 2006, 54:1772-1777.

23. Skoumal M, Haberhauer G, Kolarz G, Hawa G, Woloszczuk W, Klingler A: Serum cathepsin $\mathrm{K}$ levels of patients with longstanding rheumatoid arthritis: correlation with radiological destruction. Arthritis Res Ther 2005, 7:R65-R70.

24. Grisar J, Kapral T, Gonda G, Stamm T, Smolen JS, Aletaha D: Short term responsiveness of biomarkers to prednisolone in patients with active rheumatoid arthritis [abstract]. Ann Rheum Dis 2006, 65(Suppl II):171.

25. Gertz BJ, Shao P, Hanson DA, Quan H, Harris ST, Genant HK, Chesnut $\mathrm{CH}$ 3rd, Eyre DR: Monitoring bone resorption in early postmenopausal women by an immunoassay for cross-linked collagen peptides in urine. J Bone Miner Res 1994, 9:135-142.

26. Gertz BJ, Clemens JD, Holland SD, Yuan W, Greenspan S: Application of a new serum assay for type I collagen cross-linked $\mathrm{N}$-telopeptides: assessment of diurnal changes in bone turnover with and without alendronate treatment. Calcif Tissue Int 1998, 63:102-106.

27. Andersson ML, Petersson IF, Karlsson KE, Jonsson EN, Mansson $B$, Heinegard D, Saxne T: Diurnal variation in serum levels of cartilage oligomeric matrix protein in patients with knee osteoarthritis or rheumatoid arthritis. Ann Rheum Dis 2006, 65:1490-1494.

28. Manicourt DH, Poilvache P, Nzeusseu A, van EA, Devogelaer JP, Lenz ME, Thonar EJ: Serum levels of hyaluronan, antigenic keratan sulfate, matrix metalloproteinase 3 , and tissue inhibitor of metalloproteinases 1 change predictably in rheumatoid arthritis patients who have begun activity after a night of bed rest. Arthritis Rheum 1999, 42:1861-1869.

29. Engstrom-Laurent $A$ : Changes in hyaluronan concentration in tissues and body fluids in disease states. Ciba Found Symp 1989, 143:233-240.

30. Williams FM, Andrew T, Saxne T, Heinegard D, Spector TD, MacGregor AJ: The heritable determinants of cartilage oligomeric matrix protein. Arthritis Rheum 2006, 54:2147-2151.

31. Charni-Ben Tabassi N, Garnero P: Monitoring cartilage turnover. Curr Rheumatol Rep 2007, 9:16-24.

32. Scott DL, Grindulis KA, Struthers GR, Coulton BL, Popert AJ, Bacon PA: Progression of radiological changes in rheumatoid arthritis. Ann Rheum Dis 1984, 43:8-17.

33. Brennan $P$, Harrison B, Barrett E, Chakravarty K, Scott D, Silman AJ: A simple algorithm to predict the development of radiological erosions in patients with early rheumatoid arthritis: prospective cohort study. BMJ 1996, 313:471-476.

34. Bukhari M, Lunt M, Harrison BJ, Scott DG, Symmons DP, Silman AJ: Rheumatoid factor is the major predictor of increasing severity of radiographic erosions in rheumatoid arthritis: results from the Norfolk Arthritis Register Study, a large inception cohort. Arthritis Rheum 2002, 46:906-912.

35. Rantapaa-Dahlqvist S: Diagnostic and prognostic significance of autoantibodies in early rheumatoid arthritis. Scand $J$ Rheumatol 2005, 34:83-96.

36. Nell V, Machold KP, Stamm TA, Eberl G, Heinzl H, Uffmann M Smolen JS, Steiner G: Autoantibody profiling as early diagnostic and prognostic tool for rheumatoid arthritis. Ann Rheum Dis 2005, 64:1731-1736.

37. van Gaalen FA, van Aken J, Huizinga TW, Schreuder GM, Breedveld FC, Zanelli E, van Venrooij WJ, Verweij CL, Toes RE, de Vries RR: Association between HLA class II genes and autoantibodies to cyclic citrullinated peptides (CCPs) influences the severity of rheumatoid arthritis. Arthritis Rheum 2004 50:2113-2121.

38. De Rycke L, Verhelst X, Kruithof E, van den Bosch F, Hoffman IE, Veys EM, de Keyser F: Rheumatoid factor, but not anti-cyclic citrullinated peptide antibodies, is modulated by infliximab treatment in rheumatoid arthritis. Ann Rheum Dis 2005, 64: 299-302.

39. Kavanaugh A, Rosengren S, Lee SJ, Hammaker D, Firestein GS, Kalunian K, Wei N, Boyle DL: Assessment of rituximab's immunomodulatory synovial effects (the ARISE trial). I: clinical and synovial biomarker results. Ann Rheum Dis 2007, 67:402-408.

40. Van der Heijde DM, van Riel PL, van Leeuwen MA, van 't Hof MA, van Rijswijk MH, van de Putte LB: Prognostic factors for radiographic damage and physical disability in early rheumatoid arthritis. A prospective follow-up study of 147 patients. $\mathrm{Br} J$ Rheumatol 1992, 31:519-525.

41. Rooney M, Condell D, Quinlan W, Daly L, Whelan A, Feighery C Bresnihan B: Analysis of the histologic variation of synovitis in rheumatoid arthritis. Arthritis Rheum 1988, 31:956-963.

42. Bresnihan B, Tak PP: Synovial tissue analysis in rheumatoid arthritis. Baillieres Best Pract Res Clin Rheumatol 1999, 13: 645-659.

43. Bresnihan B, Gerlag DM, Rooney T, Smeets TJ, Wijbrandts CA, Boyle D, Fitzgerald O, Kirkham BW, Mclnnes IB, Smith M, Ulfgren AK, Veale DJ, Tak PP: Synovial macrophages as a biomarker of response to therapeutic intervention in rheumatoid arthritis: standardization and consistency across centers. J Rheumatol 2007, 34:620-622.

44. Haringman JJ, Gerlag DM, Zwinderman AH, Smeets TJ, Kraan MC, Baeten D, Mclnnes IB, Bresnihan B, Tak PP: Synovial tissue macrophages: a sensitive biomarker for response to treatment in patients with rheumatoid arthritis. Ann Rheum Dis 2005, 64:834-838.

45. Gerlag DM, Haringman JJ, Smeets $T J$, Zwinderman $A H$, Kraan MC, Laud PJ, Morgan S, Nash AF, Tak PP: Effects of oral prednisolone on biomarkers in synovial tissue and clinical improvement in rheumatoid arthritis. Arthritis Rheum 2004, 50:3783-3791

46. Haringman JJ, Gerlag DM, Smeets TJ, Baeten D, van den Bosch F, Bresnihan B, Breedveld FC, Dinant HJ, Legay F, Gram H, Loetscher P, Schmouder R, Woodworth T, Tak PP: A randomized controlled trial with an anti-CCL2 (anti-monocyte chemotactic protein 1) monoclonal antibody in patients with rheumatoid arthritis. Arthritis Rheum 2006, 54:2387-2392.

47. Vos K, Thurlings RM, Wijbrandts CA, van SD, Gerlag DM, Tak PP: Early effects of rituximab on the synovial cell infiltrate in patients with rheumatoid arthritis. Arthritis Rheum 2007, 56: 772-778.

48. Kraan MC, Versendaal $H$, Jonker M, Bresnihan B, Post WJ t Hart BA, Breedveld FC, Tak PP: Asymptomatic synovitis precedes clinically manifest arthritis. Arthritis Rheum 1998, 41:14811488.

49. Haupl T, Yahyawi M, Lubke C, Ringe J, Rohrlach T, Burmester GR, Sittinger M, Kaps C: Gene expression profiling of rheumatoid arthritis synovial cells treated with antirheumatic drugs. $J$ Biomol Screen 2007, 12:328-340.

50. Gerlag DM, Boyle DL, Rosengren S, Nash T, Tak PP, Firestein GS: Real-time quantitative PCR to detect changes in synovial gene expression in rheumatoid arthritis after corticosteroid treatment. Ann Rheum Dis 2007, 66:545-547.

51. van Leeuwen MA, Westra J, Limburg PC, van Riel PL, van Rijswijk $\mathrm{MH}$ : Clinical significance of interleukin-6 measurement in early rheumatoid arthritis: relation with laboratory and clinical variables and radiological progression in a three year prospective study. Ann Rheum Dis 1995, 54:674-677.

52. Eastgate JA, Symons JA, Wood NC, Grinlinton FM, diGiovine FS 
Duff GW: Correlation of plasma interleukin-1 levels with disease activity in rheumatoid arthritis. Lancet 1988, 2:706709.

53. Knudsen LS, Christensen IJ, Lottenburger T, Svendsen MN, Nielsen HJ, Nielsen L, Hørslev-Petersen K, Jensen JE, Kollerup G, Johansen JS: Pre-analytical and biological variability in circulating interleukin 6 in healthy subjects and patients with rheumatoid arthritis. Biomarkers 2008, 13:59-78.

54. Weyand CM, Klimiuk PA, Goronzy JJ: Heterogeneity of rheumatoid arthritis: from phenotypes to genotypes. Springer Semin Immunopathol 1998, 20:5-22.

55. Tak PP: Analyzing synovial tissue samples. What can we learn about early rheumatoid arthritis, the heterogeneity of the disease, and the effects of treatment? J Rheumatol 2005, 32 (Suppl 72):25-26.

56. Veale DJ, Ritchlin C, Fitzgerald O: Immunopathology of psoriasis and psoriatic arthritis. Ann Rheum Dis 2005, 64(Suppl 2): ii26-ii29.

57. Francois RJ, Neure L, Sieper J, Braun J: Immunohistological examination of open sacroiliac biopsies of patients with ankylosing spondylitis: detection of tumour necrosis factor alpha in two patients with early disease and transforming growth factor beta in three more advanced cases. Ann Rheum Dis 2006, 65:713-720.

58. Partsch G, Steiner G, Leeb BF, Dunky A, Broll H, Smolen JS: Highly increased levels of tumor necrosis factor-alpha and other proinflammatory cytokines in psoriatic arthritis synovial fluid. J Rheumatol 1997, 24:518-523.

59. Steiner G, Tohidast-Akrad M, Witzmann G, Vesely M, StudnickaBenke A, Gal A, Kunaver M, Zenz P, Smolen JS: Cytokine production by synovial $T$ cells in rheumatoid arthritis. Rheumatology (Oxford) 1999, 38:202-213.

60. Raza K, Falciani F, Curnow SJ, Ross EJ, Lee CY, Akbar AN, Raza K, Falciani F, Curnow SJ, Ross EJ, Lee CY, Akbar AN, Lord JM, Gordon C, Buckley CD, Salmon M: Early rheumatoid arthritis is characterized by a distinct and transient synovial fluid cytokine profile of T cell and stromal cell origin. Arthritis Res Ther 2005, 7:R784-R795.

61. Gabay C, Silacci P, Genin B, Mentha G, Le CC, Guerne PA: Soluble interleukin- 6 receptor strongly increases the production of acute-phase protein by hepatoma cells but exerts minimal changes on human primary hepatocytes. Eur J Immunol 1995, 25:2378-2383.

62. Dawes PT, Fowler PD, Clarke S, Fisher J, Lawton A, Shadforth MF: Rheumatoid arthritis: treatment which controls the Creactive protein and erythrocyte sedimentation rate reduces radiological progression. $\mathrm{Br} J$ Rheumatol 1986, 25:44-49.

63. Aletaha D, Nell VPK, Stamm T, Uffmann M, Pflugbeil S, Machold K, Smolen JS: Acute phase reactants add little to composite disease activity indices for rheumatoid arthritis: validation of a clinical activity score. Arthritis Res 2005, 7:R796-R806.

64. van Leeuwen MA, van Rijswijk MH, Sluiter WJ, van Riel PL, Kuper $\mathrm{IH}$, van de Putte LB, Pepys MB, Limburg PC: Individual relationship between progression of radiological damage and the acute phase response in early rheumatoid arthritis. Towards development of a decision support system. J Rheumatol 1997, 24:20-27.

65. Smolen JS, Van Der Heijde DM, St Clair EW, Emery P, Bathon JM, Keystone E, Maini RN, Kalden JR, Schiff M, Baker D, Han C, Han J, Bala M; Active-Controlled Study of Patients Receiving Infliximab for the Treatment of Rheumatoid Arthritis of Early Onset (ASPIRE) Study Group: Predictors of joint damage in patients with early rheumatoid arthritis treated with high-dose methotrexate without or with concomitant infliximab. Results from the ASPIRE trial. Arthritis Rheum 2006, 54:702-710.

66. St Clair EW, Wagner CL, Fasanmade AA, Wang B, Schaible T, Kavanaugh $A$, Keystone EC: The relationship of serum infliximab concentrations to clinical improvement in rheumatoid arthritis: results from ATTRACT, a multicenter, randomized, double-blind, placebo-controlled trial. Arthritis Rheum 2002, 46:1451-1459.

67. Duff GW: Cytokines and acute phase proteins in rheumatoid arthritis. Scand J Rheumatol Supp/ 1994, 100:9-19.

68. Otterness IG: The value of C-reactive protein measurement in rheumatoid arthritis. Semin Arthritis Rheum 1994, 24:91-104.

69. Charles P, Elliott MJ, Davis D, Potter A, Kalden JR, Antoni C, Breedveld FC, Smolen JS, Eberl G, deWoody K, Feldmann M,
Maini RN: Regulation of cytokines, cytokine inhibitors, and acute-phase proteins following anti-TNF-alpha therapy in rheumatoid arthritis. J Immunol 1999, 163:1521-1528.

70. Barrera P, Boerbooms AM, van de Putte LB, van der Meer JW: Effects of antirheumatic agents on cytokines. Semin Arthritis Rheum 1996, 25:234-253.

71. Lassere MN, Johnson KR, Boers M, Tugwell P, Brooks $P$, Simon L, Strand V, Conaghan PG, Ostergaard M, Maksymowych WP Landewe R, Bresnihan B, Tak PP, Wakefield R, Mease P, Bingham CO 3rd, Hughes M, Altman D, Buyse M, Galbraith S, Wells G: Definitions and validation criteria for biomarkers and surrogate endpoints: development and testing of a quantitative hierarchical levels of evidence schema. J Rheumato/ 2007, 34:607-615.

72. American College of Rheumatology Committee to Reevaluate Improvement Criteria: A proposed revision to the ACR20: the hybrid measure of ACR response [abstract]. Arthritis Rheum 2007, 57:193-202.

73. Soubrier M, Zerkak D, Gossec L, Ayral X, Roux C, Dougados M: Which variables best predict change in rheumatoid arthritis therapy in daily clinical practice? J Rheumato/ 2006, 33:12431246.

74. Kobayashi K, Takahashi N, Jimi E, Udagawa N, Takami M, Kotake S, Nakagawa N, Kinosaki M, Yamaguchi K, Shima N, Yasuda H, Morinaga T, Higashio K, Martin TJ, Suda T: Tumor necrosis factor alpha stimulates osteoclast differentiation by a mechanism independent of the ODF/RANKL-RANK interaction. J Exp Med 2000, 191:275-286.

75. Devlin RD, Reddy SV, Savino R, Ciliberto G, Roodman GD: IL-6 mediates the effects of IL-1 or TNF, but not PTHrP or $1,25(\mathrm{OH}) 2 \mathrm{D} 3$, on osteoclast-like cell formation in normal human bone marrow cultures. J Bone Miner Res 1998, 13:393399.

76. Ragab AA, Nalepka JL, Bi Y, Greenfield EM: Cytokines synergistically induce osteoclast differentiation: support by immortalized or normal calvarial cells. Am J Physiol Cell Physiol 2002, 283:C679-C687.

77. Lee ZH, Lee SE, Kim CW, Lee SH, Kim SW, Kwack K, Walsh K, $\mathrm{Kim} \mathrm{HH}$ : IL-1alpha stimulation of osteoclast survival through the PI 3-kinase/Akt and ERK pathways. J Biochem (Tokyo) 2002, 131:161-166.

78. Lam J, Takeshita S, Barker JE, Kanagawa O, Ross FP, Teitelbaum SL: TNF-alpha induces osteoclastogenesis by direct stimulation of macrophages exposed to permissive levels of RANK ligand. J Clin Invest 2000, 106:1481-1488.

79. Smolen JS, Han C, Bala M, Maini RN, Kalden JR, van der Heijde D, Breedveld FC, Furst DE, Lipsky PE; ATTRACT Study Group: Evidence of radiographic benefit of infliximab plus methotrexate in rheumatoid arthritis patients who had no clinical improvement: a detailed subanalysis of the ATTRACT Trial. Arthritis Rheum 2005, 52:1020-1030.

80. Landewe R, van der Heijde D, Klareskog L, van Vollenhoven $R$, Fatenejad S: Disconnect between inflammation and joint destruction after treatment with etanercept plus methotrexate: results from the trial of etanercept and methotrexate with radiographic and patient outcomes. Arthritis Rheum 2006, 54: 702-710.

81. St Clair EW, van der Heijde DM, Smolen JS, Maini RN, Bathon JM, Emery P, Keystone E, Schiff M, Kalden JR, Wang B, Dewoody K, Weiss R, Baker D; Active-Controlled Study of Patients Receiving Infliximab for the Treatment of Rheumatoid Arthritis of Early Onset Study Group: Combination of infliximab and methotrexate therapy for early rheumatoid arthritis: a randomized, controlled trial. Arthritis Rheum 2004, 50:3432-3443.

82. Klareskog L, van der Heijde D, de Jager JP, Gough A, Kalden J, Malaise M, Martín Mola E, Pavelka K, Sany J, Settas L, Wajdula J, Pedersen R, Fatenejad S, Sanda M; TEMPO (Trial of Etanercept and Methotrexate with Radiographic Patient Outcomes) Study Investigators: Therapeutic effect of the combination of etanercept and methotrexate compared with each treatment alone in patients with rheumatoid arthritis: double-blind randomised controlled trial. Lancet 2004, 363:675-681.

83. Breedveld FC, Weisman MH, Kavanaugh AF, Cohen SB, Pavelka $\mathrm{K}$, van Vollenhoven R, Sharp J, Perez JL, Spencer-Green GT: The PREMIER study - a multicenter, randomized, double-blind clinical trial of combination therapy with adalimumab plus methotrexate versus methotrexate alone or adalimumab 
alone in patients with early, aggressive rheumatoid arthritis who had not had previous methotrexate treatment. Arthritis Rheum 2006, 54:26-37.

84. Redlich K, Görtz B, Hayer S, Zwerina J, Doerr N, Kostenuik P, Bergmeister H, Kollias G, Steiner G, Smolen JS, Schett G: Repair of local bone erosions and reversal of systemic bone loss upon therapy with anti-tumor necrosis factor in combination with osteoprotegerin or parathyroid hormone in tumor necrosis factor-mediated arthritis. Am J Pathol 2004, 164:543-555.

85. Diarra D, Stolina M, Polzer K, Zwerina J, Ominsky MS, Dwyer D, Korb A, Smolen J, Hoffmann M, Scheinecker C, van der Heide D, Landewe R, Lacey D, Richards WG, Schett G: Dickkopf-1 is a master regulator of joint remodeling [abstract]. Nat Med 2007, 13:156-163.

86. Smolen JS, Han C, van der Heijde D, Emery P, Bathon JM, Keystone E, Maini RN, Kalden JR, Aletaha D, Baker D, Han J, Bala M, St Clair EW: Infliximab inhibits radiographic progression regardless of disease activity at baseline and following treatment in patients with early active rheumatoid arthritis [abstract]. Arthritis Rheum 2006, 54(Suppl):S231.

87. Aletaha D, Funovits J, Keystone EC, Smolen JS: Disease activity early in the course of treatment predicts response to therapy after one year in rheumatoid arthritis patients. Arthritis Rheum 2007, 56:3226-3235.

88. Schoels M, Funovits J, Muellner J, Smolen JS, Aletaha D: Disease activity at baseline and early treatment response predict longterm success of therapy in rheumatoid arthritis - results from an observational study [abstract]. Arthritis Rheum 2007, 56 (Suppl):S186.

89. Aletaha D, Eberl G, Nell VP, Machold KP, Smolen JS: Attitudes to early rheumatoid arthritis: changing patterns. Results of a survey. Ann Rheum Dis 2004, 63:1269-1275.

90. Emery $\mathrm{P}$, Breedveld FC, Dougados M, Kalden JR, Schiff $\mathrm{MH}$, Smolen JS: Early referral recommendation for newly diagnosed rheumatoid arthritis: evidence based development of a clinical guide. Ann Rheum Dis 2002, 61:290-297.

91. Goronzy JJ, Matteson EL, Fulbright JW, Warrington KJ, ChangMiller A, Hunder GG, Mason TG, Nelson AM, Valente RM, Crowson CS, Erlich HA, Reynolds RL, Swee RG, O'Fallon WM, Weyand CM: Prognostic markers of radiographic progression in early rheumatoid arthritis. Arthritis Rheum 2005, 50:43-54.

92. Ehrenstein MR, Evans JG, Singh A, Moore S, Warnes G, Isenberg $\mathrm{DA}$, Mauri C: Compromised function of regulatory $\mathrm{T}$ cells in rheumatoid arthritis and reversal by anti-TNFalpha therapy. $J$ Exp Med 2004, 200:277-285.

93. Brown AK, Quinn MA, Karim Z, Conaghan PG, Peterfy CG, Hensor E, Wakefield RJ, O'Connor PJ, Emery P: Presence of significant synovitis in rheumatoid arthritis patients with disease-modifying antirheumatic drug-induced clinical remission: evidence from an imaging study may explain structural progression. Arthritis Rheum 2006, 54:3761-3773.

94. Taylor PC: Serum vascular markers and vascular imaging in assessment of rheumatoid arthritis disease activity and response to therapy. Rheumatology (Oxford) 2005, 44:721728.

95. Wakefield RJ, D'Agostino MA, lagnocco A, Filippucci E, Backhaus M, Scheel AK, Joshua F, Naredo E, Schmidt WA, Grassi W, Moller I, Pineda C, Klauser A, Szkudlarek M, Terslev L, Balint P, Bruyn GA, Swen WA, Jousse-Joulin S, Kane D, Koski JM, O'Connor P, Milutinovic S, Conaghan PG; OMERACT Ultrasound Group: The OMERACT Ultrasound Group: status of current activities and research directions. J Rheumatol 2007, 34:848851.

96. Herwig $\mathrm{R}$, Lehrach $\mathrm{H}$ : Expression profiling of drug response from genes to pathways. Dialogues Clin Neurosci 2006, 8:283293.

97. Weljie AM, Dowlatabadi R, Miller BJ, Vogel HJ, Jirik FR: An inflammatory arthritis-associated metabolite biomarker pattern revealed by ${ }^{1} \mathrm{H}$ NMR spectroscopy. J Proteome Res 2007, 6:3456-3464.

98. Smolen JS, Aletaha D: Patients with rheumatoid arthritis in clinical care. Ann Rheum Dis 2004, 63:221-225.

99. Firestein GS, Alvaro-Gracia JM, Maki R: Quantitative analysis of cytokine gene expression in rheumatoid arthritis. J Immunol 1990, 144:3347-3353. 